\title{
The Contribution of Tourism Industry on the GDP growth of Western Balkan Countries
}

Article history:

Received: 24 April 2015

Sent for revision: 6 May 2015

Received in revised form: 28 August 2015

Accepted: 5 September 2015

Available online: 15 October 2015

Abstract: Tourism industry records various economic, social, political and others influences and provides itself important position in the overall economic development of many countries. The analysis of the available data of tourist arrivals and number of tourist overnight stays in observed countries of the Western Balkans (Serbia, Macedonia, Montenegro) led us to conduct research in order to determine tourism contribution to the overall economic growth. Based on the modified methodology used by Brida et al. (2008) for calculating real GDP growth rates and tourism contribution to the overall economic growth, the paper indicates that tourism makes a modest direct contribution to the overall economic growth in the examined countries, regardless of the continuous increase in the number of foreign tourist arrivals. The level of tourism contribution to the overall economic growth varies and it is primarily related to diversity and quality of supply (the highest contribution is recorded in Montenegro, while lowest contribution is observed in Macedonia).

Keywords: tourism industry, economic impact, GDP, Western Balkans

\section{Doprinos turističke industrije rastu BDP-a u zemljama zapadnog Balkana}

Apstrakt: Turistička industrija beleži različite ekonomske, društvene, političke i druge uticaje koji joj obezbeđuju važnu poziciju u ukupnom privrednom

\footnotetext{
${ }^{1}$ Singidunum University, Faculty of Tourism and Hospitality Management, Serbia

2 Singidunum University, Faculty of Tourism and Hospitality Management, Serbia, mknezevic@singidunum.ac.rs

$3_{3}$ Singidunum University, Faculty of Business, Serbia

${ }^{4}$ Singidunum University, Faculty of Tourism and Hospitality Management, Serbia
} 
Cerović S. et al.: The Contribution of Tourism Industry on the GDP growth of Western..

razvoju velikog broja zemalja. Analiziranje dostupnih podataka o kretanju turista i noćenjima koja su ostvarili u zemljama koje smo posmatrali navelo nas je da naše istraživanje usmerimo ka izračunavanju doprinosa turizma ukupnom ekonomskom rastu. Koristeći modifikovanu metodologiju koju su upotrebili Brida, Pereyra i Deves (2008), za izračunavanje stope rasta realnog GDP-a i doprinosa turizma ukupnom ekonomskom rastu, u ovom radu smo pokazali da turizam, uprkos kontinuiranom povećanju broja stranih turista, ima skroman direktni doprinos ukupnom ekonomskom rastu zemalja Zapadnog Balkana (Srbija, Makedonija, Crna Gora). Stepen doprinosa turizma ekonomskom rastu u posmatranim zemljama je različit i značajno vezan za raznovrsnost i kvalitet ponude (najveći doprinos ekonomskom rastu turizam ima u Crnoj Gori a najmanji u Makedoniji)

Ključne reči: turistička industrija, ekonomski uticaj, GDP, Zapadni Balkan

\section{Introduction}

Tourism improvement is continuously seen as a basic instrument in progressing economic development, alleviating poverty, and advancing food security (Richardson, 2010). Tourism industry constitutes a vital fragment of the economy of any country and applies impressive financial, political and social effect, thus securing itself an unmistakable position in the general worldwide economic and social advancement (Čačić, 2013). It has shown a fairly positive pattern in the course of recent decades (Wang et al. 2012; Ma \& Hassink, 2013; Temirbulatova \& Borza, 2015). Notwithstanding the way in which it has experienced a few emergencies activated by various economic and non-economic elements, it has figured out how to recuperate quicker and record higher development rates in connection to the whole world economy (Eugenio-Martin \& Campos-Soria, 2014; Čerović et. al. 2015). Likewise, tourism industry has of late turned into an imperative fragment of the worldwide economy (Lew, 2011; Sharpley \& Telfer, 2015). Weaver \& Lawton (2010) determine that tourism is progressively turning into an economic giant, while Holloway characterizes it as the absolute most imperative economic activity on the planet (Holloway et al. 2009). Tourism is commonly seen as an essential actuator for the economic development, serving to build the economic welfare of countries (Webster \& Ivanov, 2014). It brings numerous advantages, particularly in terms of job creation and employment of individuals who provide tourism services (Pender \& Sharpley, 2005). This industry is often seen as an activity that can contribute to increasing employment, because it has the fast development in a large number of destinations, it's diverse and resilient, labor intensive and has a wide range of jobs (Inkson \& Minnaert, 2012). The vital significance of tourism for the economy is given by its commitment, direct and indirect, to the constitution of 
Cerović S. et al.: The Contribution of Tourism Industry on the GDP growth of Western..

the Gross Domestic Product (GDP). The economic effect of tourism essentially alludes to tourism consumption (one part of GDP people use for travel), which applies significant effect on the economy of the given nations (Unković \& Zečević, 2014). As indicated by Taušer et al. (2015) GDP has critical impact on the buying force of consumers and in this way influences the economic development and the local economies. Universally, tourism has empowered the GDP overflow from the most developed economic states to those with lower Gross domestic product (Sekulović, 2012; Blanke \& Chiesa, 2013). Therefore, this paper shall elaborate on tourism industry results achieved by the countries of the Western Balkans. The survey encompassed Serbia, Macedonia and Montenegro, while the emphasis was placed on the contribution of tourism sector to the GDP in the observed countries. As previously stated, these three countries are not EU members, but are granted an official candidate status. Thus, our main aim is to determine how tourism results affect macroeconomic indicators, i.e., determine tourism contribution to the overall economic growth and development of these countries.

\section{The results achieved in tourism sector of Serbia, Macedonia and Montenegro}

With a specific end goal to focus on commitment of tourism industry to the general economic growth, we might present the outcomes accomplished in tourism of Serbia, Macedonia and Montenegro, fundamentally through the quantity of tourist entries and their overnight stays.

Table 1. Tourist arrivals and overnight stays in Serbia for the period 2006-2014.

\begin{tabular}{|c|c|c|c|c|c|c|}
\hline \multicolumn{7}{|c|}{ Tourist arrivals and overnight stays, 2000 - 2014 Serbia } \\
\hline & \multicolumn{3}{|c|}{ Tourist arrivals } & \multicolumn{3}{c|}{ Overnight stays } \\
\cline { 2 - 7 } & total & domestic & foreign & total & domestic & foreign \\
\hline 2006 & 1889771 & 1420929 & 468842 & 6407225 & 5391913 & 1015312 \\
\hline 2007 & 2306558 & 1610513 & 696045 & 7328692 & 5853017 & 1475675 \\
\hline 2008 & 2266166 & 1619672 & 646494 & 7334106 & 5935219 & 1398887 \\
\hline 2009 & 2018466 & 1373444 & 645022 & 6761715 & 5292613 & 1469102 \\
\hline 2010 & 2000597 & 1317916 & 682681 & 6413515 & 4961359 & 1452156 \\
\hline 2011 & 2068610 & 1304443 & 764167 & 6644738 & 5001684 & 1643054 \\
\hline 2012 & 2079643 & 1269676 & 809967 & 6484702 & 4688485 & 1796217 \\
\hline 2013 & 2192435 & 1270667 & 921768 & 6567460 & 4579067 & 1988393 \\
\hline 2014 & 2192268 & 1163536 & 1028732 & 6086275 & 3925221 & 2161054 \\
\hline
\end{tabular}

Source: Author's research (based on the data of the Statistical Office of the Republic of Serbia) 
Cerović S. et al.: The Contribution of Tourism Industry on the GDP growth of Western..

According to the Statistical Office of the Republic of Serbia, slight increases and decreases were observed in the overall number of tourist arrivals during the period 2006-2014 (table 1). It is quite evident that the structure of tourists has significantly altered (a continuous increase could be observed in the number of foreign tourists, while the number of domestic tourists was constantly decreasing). During the period 2007-2010, a continuous fall was observed in the overall number of foreign tourist arrivals in Serbia. After 2011 and 2012, a slight increase could be observed. Almost identical results could be observed in 2014 for the total number of tourist arrivals, while the structure slightly changed compared to 2013. The number of domestic tourists (1.163.536) decreased by $8,4 \%$, while the number of foreign tourists (1.028.732) increased by $11,6 \%$, compared to the previous year (The Statistical Office of the Republic of Serbia, 2014.).

Table 2. Tourist arrivals and overnight stays in Macedonia for the period 2006-2014.

\begin{tabular}{|c|c|c|c|c|c|c|}
\hline \multicolumn{6}{|c|}{ Tourist arrivals and overnight stays, 2000 - 2014 Macedonia } \\
\hline & \multicolumn{3}{|c|}{ Tourist arrivals } & \multicolumn{3}{c|}{ Overnight stays } \\
\cline { 2 - 7 } & total & domestic & foreign & total & domestic & foreign \\
\hline 2006 & 499473 & 297116 & 202357 & 1917395 & 1474550 & 442845 \\
\hline 2007 & 536212 & 306132 & 230080 & 2019712 & 1501624 & 518088 \\
\hline 2008 & 605320 & 350363 & 254957 & 2235520 & 1648073 & 587447 \\
\hline 2009 & 587770 & 328566 & 259204 & 2101606 & 1517810 & 583796 \\
\hline 2010 & 586241 & 324545 & 261696 & 2020217 & 1461185 & 559032 \\
\hline 2011 & 647568 & 320097 & 327471 & 2173034 & 1417868 & 755166 \\
\hline 2012 & 663633 & 312274 & 351359 & 2151692 & 1339946 & 811746 \\
\hline 2013 & 701794 & 302114 & 399680 & 2157175 & 1275800 & 881375 \\
\hline 2014 & 735650 & 310336 & 425314 & 2195883 & 1273370 & 922513 \\
\hline
\end{tabular}

Source: Author's research (based on the data of the State Statistical Office of the former Yugoslav Republic of Macedonia)

Upon reviewing the number of overnight stays, it can be concluded that it was decreasing in the period 2008- 2010. A slight increase was observed in 2011, while the number of overnight stays was slightly higher in 2012 compared to 2010. A mild increase was observed in 2013 compared to 2012 (about 1.5\%), followed by a new decrease in 2014 (around 7,5\%) compared to the previous year. Based on the structure and the growth rate of overnight stays, stagnation and a slight drop could be observed for the overall number of overnight stays and overnight stays of domestic tourists. However, a continuous increase in the number of overnight stays of foreign tourists was 
Cerović S. et al.: The Contribution of Tourism Industry on the GDP growth of Western.

recorded until 2013 (an increase of 65\% compared to 2005), followed by a decrease in 2014 (due to the reduced number of tourist arrivals).

According to the State Statistical Office of the Former Yugoslav Republic of Macedonia, a similar tendency could be observed as in Serbia - a decrease in the number of tourist arrivals and overnight stays is observed after an increase recorded during the period 2006-2008 (table 2). Following this threeyear drop (2008- 2010), a slight increase could be observed in the overall number of tourist arrivals in Macedonia during the period 2011-2014. As it can be seen, the number of foreign tourists was increasing and the number of domestic tourists was decreasing each year, despite a drop in the overall number of tourists in the given period. On the other hand, a greater number of overnight stays was realized by domestic than by foreign tourists in all of the surveyed years.

Table 3. Tourist arrivals and overnight stays in Montenegro for the period 2006-2014.

\begin{tabular}{|c|c|c|c|c|c|c|}
\hline \multicolumn{6}{|c|}{ Tourist arrivals and overnight stays, 2000 - 2014 Montenegro } \\
\hline & \multicolumn{3}{|c|}{ Tourist arrivals } & \multicolumn{3}{c|}{ Overnight stays } \\
\cline { 2 - 7 } & total & domestic & foreign & total & domestic & foreign \\
\hline 2006 & 953961 & 156857 & 797071 & 5936270 & 909607 & 5026663 \\
\hline 2007 & 1133432 & 149294 & 984138 & 7294530 & 851045 & 6443485 \\
\hline 2008 & 1188116 & 156904 & 1031212 & 7794741 & 828462 & 6966279 \\
\hline 2009 & 1207694 & 163680 & 1044014 & 7552006 & 856332 & 6695674 \\
\hline 2010 & 1262985 & 175191 & 1087794 & 7964893 & 987033 & 6977860 \\
\hline 2011 & 1373454 & 172355 & 1201099 & 8775171 & 956368 & 7818803 \\
\hline 2012 & 1439500 & 175337 & 1264163 & 9151236 & 1008229 & 8143007 \\
\hline 2013 & 1492006 & 167603 & 1324403 & 9411943 & 997728 & 8414215 \\
\hline 2014 & 1517376 & 167079 & 1350297 & 9553783 & 957127 & 8596656 \\
\hline
\end{tabular}

Source: Author's research (based on the MONSTAT statistics)

According to MONSTAT (the Statistical Office of the Republic of Montenegro), the situation in this country quite differs from the situation in Serbia and Macedonia. Namely, throughout the surveyed period (2006-2014), Montenegro recorded an increase in the overall number of tourist arrivals, in particular foreign tourists (table 3). A slight drop in the number of tourist arrivals is observed only for domestic tourists in 2007 compared to 2006, as well as in 2013 and 2014. The same goes for the overall number of overnight stays, as well as the number of overnight stays of foreign tourists, whereas the number of overnight stays of domestic tourists in 2013 and 2014 was lower than in previous years. 
Cerović S. et al.: The Contribution of Tourism Industry on the GDP growth of Western..

According to the World Travel \& Tourism Council, the achieved tourism results considerably contribute to total GDP (Table 4).

Table 4. The overall contribution of tourism to GDP (\%)

\begin{tabular}{|c|c|c|c|c|c|c|c|}
\hline & $\mathbf{2 0 0 7}$ & $\mathbf{2 0 0 8}$ & $\mathbf{2 0 0 9}$ & $\mathbf{2 0 1 0}$ & $\mathbf{2 0 1 1}$ & $\mathbf{2 0 1 2}$ & $\mathbf{2 0 1 3}$ \\
\hline World & 9,6 & 9,4 & 9,3 & 9 & 9,1 & 9,2 & 9,3 \\
\hline Europe & 8,1 & 8 & 8 & 7,7 & 7,6 & 7,7 & 7,6 \\
\hline Macedonia & 5,1 & 5,2 & 5,2 & 5,1 & 5,2 & 5,5 & 5,7 \\
\hline Montenegro & 21,6 & 24 & 16 & 15,7 & 17,1 & 19,7 & 22,9 \\
\hline Serbia & 6,1 & 5,9 & 5,7 & 7,8 & 8 & 8 & 8 \\
\hline
\end{tabular}

Source: WTTC (http://www.wttc.org)

These indicators (of overall contribution including direct, indirect and multiplied tourism effects) show that tourism has a considerable bearing on generating GDP in the surveyed countries. This has encouraged us to conduct research and calculate direct tourism contribution to the overall economic growth of those countries.

\section{Research}

The principal purpose of this paper is to determine and present the contribution of tourism sector to gross domestic product (GDP) of Serbia, Macedonia and Montenegro over the past 10 years, as the most crucial period in the EU integration process. Also, the authors intend to examine and compare the results obtained and highlight differences between the surveyed countries concerning the contribution of tourism sector to the overall economic growth. The two most commonly used methodologies for performing such analyses are TSA (Tourism Satellite Account) and CGE (Computable General Equilibrium) (Dupeyras \& MacCallum, 2013). Namely, CGE model takes into account the fact that tourism is one of many sectors (constituting the economy of a country) that is struggling with various other sectors to obtain scarce (state) funds (Dwyer et al. 2003)(Brida et al. 2008). Numerous authors have examined and written about the CGE model in their research and scientific papers (primarily the effects of tourism impact growth on the key macroeconomic indicators, thus pointing to the tendency of "excluding" other industry sectors. Blake et al. (2000) believe that CGE model is an important instrument intended for business people who design business policy of a company and its long-term business plans. By comparing it with the input- 
Cerović S. et al.: The Contribution of Tourism Industry on the GDP growth of Western..

output analysis method, CGE model can link feedback effects among various types of industries and resource limitations, even though the input-output analysis is most frequently used for measuring tourism impact (Zhou et al. 1997). The results of the input-output method reflect extreme optimism concerning the effects of tourism growth on costs, profit, employability and numerous other indicators (Blake, 2001) (Blake et.al, 2006). According to the CGE model, research on tourism sector contribution to the overall economic growth of a country, similar to that conducted for Indonesia (Sugiyarto et al. 2003), Hawaii (Zhou et al. 1997) and Scotland (Blake et al. 2006), shows that tourism can affect economic prosperity of a destination, thus altering the terms of trade (turnover) in its favor. Also, research indicates that contribution of tourism sector to the overall economic growth is much more modest than forecasted by the input-output analysis.

Brida et al. (2008) have implemented the modified methodology of Ivanov and Webster to Uruguay, Brazil, Mexico and Argentina. Namely, Ivanov and Webster (2007) presented their methodology for measuring tourism sector contribution to the overall economic growth of a country, on a sample comprising Cyprus, Greece and Spain. Their method uses a real GDP growth rate per capita as a measure of economic growth and differentiates it from the economic growth generated by tourism and economic growth generated by other industries. This type of measurement enables perceiving solely direct effects of tourism activities on GDP, which is a limiting factor (limitation) of this methodology in terms of the results obtained on the effects of tourism on the overall economic growth.

\subsection{Methodology}

The main obstacle we encountered while conducting research on the impact and contribution of tourism sector to economic growth was the fact that neither Serbia nor the other two surveyed countries offer adequate and easily accessible data. Therefore, we used the available data on the results achieved in tourism, in particular those related to accommodation services (hotels), food and beverages (restaurants), as the only available official sources. We have relied on the statistics of several official institutions for collecting relevant information, including the Statistical Office of the Republic of Serbia, the Statistical Office of Montenegro (MONSTAT) and the State Statistical Office of the Former Yugoslav Republic of Macedonia.

Based on the methodology used by Brida et al. (2008) for calculating the real GDP growth rate per capita $\left(g_{r}\right)$ at constant prices, we have used the following formula as a measure of economic growth: 
Cerović S. et al.: The Contribution of Tourism Industry on the GDP growth of Western..

$$
g_{r}=\left(\frac{\frac{\sum_{t} Y_{r\left(p_{0}\right)}^{T}}{N_{r}}-\frac{\sum_{t} Y_{r-1\left(p_{0}\right)}^{T}}{N_{r-1}}}{\frac{Y_{r-1\left(p_{0}\right)}}{N_{r-1}}}\right)
$$

where $\frac{\sum_{t} Y_{r\left(p_{0}\right)}^{T}}{N_{r}}$ is the total GDP in the period $r$ at constant prices $p_{0}$, while $N_{r}$ is the number of inhabitants during the period $r$. Afterwards, we divided the total GDP into tourism generated GDP and GDP generated by other sectors.

$$
g_{r}=\left(\frac{\frac{Y_{r\left(p_{0}\right)}^{T}}{N_{r}}-\frac{Y_{r-1\left(p_{0}\right)}^{T}}{N_{r-1}}}{\frac{Y_{r-1\left(p_{0}\right)}}{N_{r-1}}}+\frac{\frac{\sum_{t \neq T} Y_{r\left(p_{0}\right)}^{T}}{N_{r}}-\frac{\sum_{t \neq T} Y_{r-1\left(p_{0}\right)}^{T}}{N_{r-1}}}{\frac{Y_{r-1\left(p_{0}\right)}}{N_{r-1}}}\right)
$$

and we got the formula for calculating direct contribution of tourism sector to the overall economic growth during the period $r$.

$$
g_{r}^{T}=\left(\frac{\frac{Y_{r\left(p_{0}\right)}^{T}}{N_{r}}-\frac{Y_{r-1\left(p_{0}\right)}^{T}}{N_{r-1}}}{\frac{Y_{r-1\left(p_{0}\right)}}{N_{r-1}}}\right)
$$

Thus, $g_{r}^{T}$ represents the way of measuring contribution of tourism sector to the overall economic growth, which is calculated using the real GDP growth rate and the aforementioned formula.

\subsection{Research results and discussions}

Based on the statistics provided by the above-given official institutions and previously presented methodology, we have obtained the results shown in the table below (Table 5). It is evident that only Montenegro (with the exception of the year 2012) records positive GDP per capita growth rates (at constant prices). Unlike Montenegro, negative growth rates are recorded in Serbia in 2009, 2010, and 2012, as well as in Macedonia in 2009 and 2012. It could be concluded that negative GDP growth rates in 2009 and 2010 in Serbia and Macedonia are the result of the global crisis that affected the entire world. However, such decrease was slightly mitigated in Montenegro owing to its favorable tourism results (increased number of tourist arrivals, overnight stays 
Cerović S. et al.: The Contribution of Tourism Industry on the GDP growth of Western..

and tourism consumption), which further indicates that tourism contribution is much greater in Montenegro than in Serbia and Macedonia.

Table 5: The impact of tourism on the economic growth of the surveyed countries (\%)

\begin{tabular}{|c|c|c|c|c|c|c|c|c|c|c|c|}
\hline \multicolumn{12}{|c|}{ SERBIA } \\
\hline & 2003 & 2004 & 2005 & 2006 & 2007 & 2008 & 2009 & 2010 & 2011 & 2012 & 2013 \\
\hline $\begin{array}{l}\text { Growth of } \\
\text { GDP per } \\
\text { capita in } \\
\text { constant } \\
\text { prices }\end{array}$ & 17.15 & 10.86 & 3.87 & 18.66 & 25.26 & 12.73 & -5.45 & -2.06 & 8.53 & -2.24 & 16.91 \\
\hline $\begin{array}{l}\text { Contribution } \\
\text { of tourism } \\
\text { to economic } \\
\text { growth }\end{array}$ & 0.28 & 0.09 & 0.02 & 0.24 & 0.47 & 0.01 & -0.17 & 0.07 & 0.05 & 0.03 & 0.01 \\
\hline \multicolumn{12}{|c|}{ MONTENEGRO } \\
\hline & 2003 & 2004 & 2005 & 2006 & 2007 & 2008 & 2009 & 2010 & 2011 & 2012 & 2013 \\
\hline $\begin{array}{l}\text { Growth of } \\
\text { GDP per } \\
\text { capita in } \\
\text { constant } \\
\text { prices }\end{array}$ & 5.28 & 12.80 & 10.10 & 13.33 & 20.39 & 20.34 & 1.31 & 4.61 & 4.76 & -1.71 & 3.15 \\
\hline $\begin{array}{l}\text { Contribution } \\
\text { of tourism } \\
\text { to economic } \\
\text { growth }\end{array}$ & 0.60 & 0.19 & 1.22 & 0.28 & 0.88 & 1.77 & 0.25 & 1.08 & 0.16 & 1.50 & 0.07 \\
\hline \multicolumn{12}{|c|}{ MACEDONIA } \\
\hline & 2003 & 2004 & 2005 & 2006 & 2007 & 2008 & 2009 & 2010 & 2011 & 2012 & 2013 \\
\hline $\begin{array}{l}\text { Growth of } \\
\text { GDP per } \\
\text { capita in } \\
\text { constant } \\
\text { prices }\end{array}$ & 5.35 & 5.84 & 10.79 & 9.76 & 12.80 & 13.34 & -8.62 & 4.85 & 6.55 & -1.63 & 2.07 \\
\hline $\begin{array}{l}\text { Contribution } \\
\text { of tourism } \\
\text { to economic } \\
\text { growth }\end{array}$ & 0.08 & -0.03 & 0.25 & 0.27 & 0.22 & 0.08 & 0.16 & -0.01 & -0.06 & 0.22 & 0.01 \\
\hline
\end{tabular}

As regards tourism sector contribution to the overall economic growth and considering the results obtained, it could be concluded that such contribution is rather modest in all of the surveyed countries. Actually, tourism contribution is most evident in Montenegro (it is worth mentioning that there are huge differences in the characteristics of the surveyed countries as tourism destinations-Serbia and Macedonia have no access to the sea). Hence, 
Cerović S. et al.: The Contribution of Tourism Industry on the GDP growth of Western..

tourism contribution is significantly lower in the other two countries, in particular Macedonia. As previously stated, it is the direct contribution of tourism sector to the overall economic growth (tourism contribution would be greater if we included indirect and multiplied effects of tourism on the overall economy) ${ }^{5}$. A decrease in tourism contribution in Serbia could be observed in 2008 (0.01\%), 2009 (-0.17\%), 2011 (0.05\%), 2012 (0.03\%), and 2013 $(0.01 \%)$, while the number of tourists (in particular foreign) and overnight stays considerably increased during the observed period (Table 1). This issue could be further explored in some of our future works.

\section{Conclusion}

Despite the fact that tourism represents an activity that exerts considerable economic, political, cultural and social impact, and taking into account the results obtained, it could be concluded that direct tourism contribution to the overall economic growth in Serbia, Macedonia and Montenegro is low. The level of tourism contribution to the overall economic growth in the surveyed countries varies and it primarily depends on diversity and quality of supply (the largest contribution of tourism to the overall economic growth is observed in Montenegro, as it has an access to the sea, Macedonia generates the lowest tourism contribution, while Serbia occupies the middle position). It is worth mentioning that all of the surveyed countries show a growing tendency in terms of the number of foreign tourist arrivals. Therefore, it is necessary to adjust tourism supply with the international tendencies in the tourism market, in order to incite positive effects on the entire economy. The growing tendency in the number of foreign tourist arrivals in the surveyed countries can be positively assessed from the aspect of EU integrations, as such increase can be directly correlated with it (EU accession affects the attitudes of foreigners, countries become more open and accessible, legal regulations alter, etc.). The scope of the study leaves space for further research that could examine the possibility of comparing the results achieved by the EU states with the results generated by non-EU member states.

\section{References}

Blake, A., \& et al., (2001). Modelling Tourism and Travel Using Tourism Satellite Accounts and Tourism Policy and Forecasting Models. Retrieved from http://www.nottingham.ac.uk/ttri/pdf/2001 4.pdf

\footnotetext{
${ }^{5}$ Multiplication coefficient is over 6 in developed tourism countries and around 3 in those less developed tourism countries.
} 
Cerović S. et al.: The Contribution of Tourism Industry on the GDP growth of Western..

Blake, A., \& et al., (2006). Integrating forecasting and CGE models: The case of tourism in Scotland. Tourism Management,27, 292-305. doi:10.1016/j.tourman.2004.11.005

Blanke, J., \& Chiesa, T. (2013). The Travel \& Tourism Competitiveness Report. Geneva: World Economic Forum.

Brida, J.G., \& et al., (2008). Evaluating the contribution of tourism to economic growth. Anatolia: An International Journal of Tourism and Hospitality Research, 19(2), 351-356. doi:10.1080/13032917.2008.9687079

Chen, M.H. (2010). The economy, tourism growth and corporate performance in the Taiwanese hotel industry. Tourism Management, 31(5), 665-675. doi:10.1016/j.tourman.2009.07.011

Čačić, K. (2013). Poslovanje hotelskih preduzeća. Beograd: Univerzitet Singidunum.

Čerović, S., \& et al., (2015). The Impact of Economic Crisis and Non-Economic Factors on the Tourism Industry in Zlatibor.The European Journal of Applied Economics, 12(1), 1-9. doi:10.5937/ejae12-8160

Dupeyras, A., \& MacCallum, N. (2013). Indicators for Measuring Competitiveness in Tourism: A Guidance Document. OECD Publishing. doi:10.1787/5k47t9q2t923en

Dwyer, L., \& et al., (2003). Inter-industry Effects of Tourism Growth: Implications for Destination Managers. Tourism Economics, 9(2), 117-132. doi:10.5367/000000003101298303

Eugenio-Martin, J.L., \& Campos-Soria, J.A. (2014). Economic crisis and tourism expenditure cutback decision. Annals of Tourism Research, 44, 53-73. doi:10.1016/j.annals.2013.08.013

Frechtling, D.C. (2010). The tourism satellite account: A primer. Annals of Tourism Research, 37(1), 136-153. doi:10.1016/j.annals.2009.08.003

Holloway, C.J., \& et al., (2009). The Business of Tourism. London: Pearson.

Inkson, C., \& Minnaert, L. (2012). . Tourism Management, An Introduction, SAGE Publication: London.

Ivanov, S., \& Webster, C. (2007). Measuring the impact of tourism on economic growth. Tourism Economics, 13(3), 379-388. doi:10.5367/000000007781497773

Lee, C.C., \& Chang, C.P. (2008). Tourism development and economic growth: A closer look at panels. Tourism management, 29(1), 180-192. doi:10.1016/j.tourman.2007.02.013

Lew, A.A. (2011). Tourism's role in the global economy. Tourism Geographies: An International Journal of Tourism Space, Place and Environment, 13(1), 148-151. doi:10.1080/14616688.2010.531046

Ma, M., \& Hassink, R. (2013). An evolutionary perspective on tourism area development. Annals of Tourism Research, 41, 89-109. doi:10.1016/j.annals.2012.12.004

Marttinen, P., Pirinen, M., Sarin, A.P., Gillberg, J., Kettunen, J., Surakka, I., \& Kaski, S. (2014). Assessing multivariate gene-metabolome associations with rare variants using Bayesian reduced rank regression. Bioinformatics, doi:10.1093/bioinformatics/btu140

Mullahy, J. (2015). Multivariate fractional regression estimation of econometric share models. Journal of Econometric Methods, 4(1), 71-100. doi:10.1515/jem-20120006 
Cerović S. et al.: The Contribution of Tourism Industry on the GDP growth of Western..

Munjal, P. (2013). Measuring the economic impact of the tourism industry in India using the Tourism Satellite Account and input-output analysis. Tourism Economics, 19(6), 1345-1359. doi:10.5367/te.2013.0239

Pender, L., \& Sharpley, R. (2005). The Management of Tourism. London: SAGE Publication.

Richardson, R.B. (2010). The Contribution of Tourism to Economic Growth and Food Security. USAID Mali, Office of Economic Growth. Retrieved from http://ageconsearch.umn.edu/bitstream/97140/2/Tourism and food security in Mali A4.pdf

Ridderstaat, J., Croes, R., \& Nijkamp, P. (2014). Tourism and Long-run Economic Growth in Aruba. International Journal of Tourism Research, 16(5), 472-487. doi:10.1002/jtr.1941

Sekulović, N. (2012). Turizam u uslovima delovanja krize. Beograd: Univerzitet Singidunum.

Sharpley, R., \& Telfer, D.J. (2015). Tourism and development: Concepts and issues. Bristol: Channel View Publications.

Sugiyarto, G., Blake, A., \& Sinclair, M.T. (2003). Tourism and globalization: Economic impact in Indonesia. Annals of Tourism Research, 30(3), 683-701. doi:10.1016/S0160-7383(03)00048-3

Taušer, J., \& et al., (2015). Czech exports and German GDP: A closer look. Prague Economic Papers, 24(1), 17-37. doi:10.18267/j.pep.498

Temirbulatova, M., \& Borza, M. (2015). Multifunctional development of rural areas of kazakhstanwith the application of the unified model of tourism in the context of sustainable development and the green economy. European Scientific Journal, 11(1), 200-216.

Unković, S., \& Zečević, B. (2014). Ekonomika turizma. Beograd: Ekonomski fakultet u Beogradu, Centar za izdavačku delatnost.

Wang, Z.P., \& et al., (2012). Spatial Strategic Orientation and Distribution of the Tourism Development in Minority Areas: A Case of Linxia Hui Autonomous Prefecture. Advanced Materials Research, 361-363, 1748-1751. doi:10.4028/www.scientific.net/AMR.361-363.1748

Weaver, D., \& Lawton, L. (2010). Tourism Management. Milton: Wiley \& Sons.

Webster, C., \& Ivanov, S. (2014). Transforming competitiveness into economic benefits: Does tourism stimulate economic growth in more competitive destinations. Tourism Management, 40, 137-140. doi:10.1016/j.tourman.2013.06.003

Zhou, D., \& et al., (1997). Estimating economic impacts from tourism. Annals of Tourism Research, 24(1), 76-89.

Retrieved from http://webrzs.stat.gov.rs/WebSite/Public/PageView.aspx?pKey=2

Retrieved from http://www.monstat.org/cg/page. php?id=19\&pageid=19

Retrieved

http://www.stat.gov.mk/GSearch en.aspx?cx=005984792435174779271\%3Av7t 0sn-wu1a\&cof=FORID\%3A10\&ie=UTF-8\&q=GDP+in+real+price\&sa=Search

Retrieved from http://www.wttc.org//media/files/reports/economic\%20impact\%20research/countries\%202015/serbia 2015.pdf

(2015) Retrieved from http://www.e-unwto.org/doi/book/10.18111/9789284416899 